\title{
Gyógynövény készítmények kockázatértékelése a „Biztonságos étrend-kiegészítő program" keretében
}

\section{Bérci lstván}

Magyarországi Étrend-kiegészítő Gyártók és Forgalmazók Egyesülete, 2921 Komárom, Kőolaj u. 2.

e-mail:mekisz@mekisz.hu

Az elmúlt hónapokban számos fórumon előkerült a „Biztonságos étrend-kiegészítő program”, amelynek sikeres múködéséhez nem csupán a létrehozói (a Magyar Gyógyszerészi Kamara, a Gyógyszer-nagykereskedők Szövetsége, a Magyarországi Gyógyszergyártók Országos Szövetsége, a Hamisítás Elleni Nemzeti Testület és a Magyar Étrend-kiegészítő Gyártók és Forgalmazók Egyesülete), hanem minden piaci szereplő: gyártók, forgalmazók, gyógyszerészek, hatóságok, fogyasztók is nagy reményeket füznek. Közös elkötelezettség egy olyan rendszer létrehozása, amely a hatósági folyamatokat támogatva segíteni tudja a nem megfelelő minőségú termékek piacra jutásának megakadályozását. Ez különösen igaz a notifikációs rendszer tavaly novemberi átalakulása óta, mely formális folyamattá tette a bejelentések tudomásulvételéről szóló OGYÉl határozatok kiadását.

Napjainkban a kockázatértékeléseknek jól elfogadott gyakorlata van, de a megfelelő eljárás kiválasztása során meg kell találni az egyensúlyt a kellő szigorúság és a rendszer működőképességét biztosító racionalistás között. Az előadásban beszámolunk a „Biztonságos étrend-kiegészítő program” keretében folyó kockázatértékelésről, az abban rejlő lehetőségekről, de szembenézünk a rendszer korlátaival is. 